Naydenova, M. (2020). Glass art objects - between fine and applied art. 21st century: history and modernity of art. Collection of Scientific Articles. European Scientific e-Journal, 4 (4), 84-98. Hlučín-Bobrovníky: "Anisiia Tomanek" OSVČ.

Найленова, М. (2020). Художествени обекти от стькло - межАу изящното и приложното изкуство. 21st century: history and modernity of art. Collection of Scientific Articles. European Scientific e-Journal, 4 (4), 84-98. Hlučín-Bobrovníky: "Anisiia Tomanek" OSVČ.

DOI: $10.47451 /$ art2020-12-002

EOI: $10.11244 / \operatorname{art} 2020-12-002$

The paper is published in Crossref, Internet Archive, Google Scholar, Academic Resource Index ResearchBib, JGate, ISI, CiteFactor, ICI, eLibrary databases.

\author{
Monika Naydenova \\ $\mathrm{PhD}$ of Art History and Fine Arts \\ Senior Associate \\ Department of Visual Arts \\ New Bulgarian University \\ Sofia, Bulgaria \\ E-mail: studio@mohika.bg
}

\title{
Glass art objects - between fine and applied art
}

Abstract:

The article describes the interrelationships that emerged between art, crafts, technology and design, in the period from the second half of the 19th century to the present day. Attention is paid to the classification of a work and the delineation of the category 'Object'. The object of this research is contemporary art in the context of its classification as fine and applied in the period from the second half of the 19th century to the present day. Our attention will be focused on the glass material as a means of expression. The task of the research is to trace the metamorphoses that fine and applied art goes through and to what extent this is determined by the context in which the work lives.

Keywords:

fine art, applied art, art objects, glass art, contemporary art.

Моника Найденова

Аоктор по Изкуствознание и изобразителни изкуства

Асистент

Аепартамент Изящни изкуства

Нов бъмгарски университет София, Бъмгария

E-mail: studio@mohika.bg

\section{ХУАожествени обекти от стъкАо - межАУ изящното и \\ приможното изкуство}


Резгоме:

Статията описва взаимовръзките, възникнали межАу изкуството, занаятите, технологиите и Аизайна, през периода от втората половина на 19 век до наши дни. Обрыща се внимание на класификацията на произведение и очертаването на категорията „Обект“. Обект на това изследване е съвременното изкуство в контекста на класифицирането му като изящно и приложено в периода от втората половина на 19 век до наши Ани. Вниманието ни ще бъде насочено към стькления материал като изразно средство. Задачата на изследването е Аа проследи метаморфозите, през които преминава изобразителното и приложното изкуство и до каква степен това се определя от контекста, в който произведението живее.

Клточови думи:

изящно изкуство, приложно изкуство, художествени обекти, художествено стькАо, съвременно изкуство.

\section{Introduction}

The object of this research is contemporary art in the context of its classification as fine and applied in the period from the second half of the 19th century to the present day. Our attention will be focused on the glass material as a means of expression.

The subject of the research is the transformation of utilitarian objects into works of contemporary art. The place of design and the dominance of artistic qualities in practical items. Differentiation of the category 'object' and its presence on the art scene to date.

The task of the research is to trace the metamorphoses that fine and applied art goes through and to what extent this is determined by the context in which the work lives. We will pay more attention to glass objects and their characteristics. The present study is also based on a number of publications in specialized publications in the field of glass, monographs on specific issues concerning the topic, theoretical publications, internet sources with periodicals in the field of art glass. All of them do not consider the category 'object' and specifically those made of glass. Based on this, the study would be an up-to-date look at the changing art scene and in particular the presence of glass objects on it.

\section{1.}

Glass has a long and dynamic history. It is at the same time an ancient material with an extremely current presence. Through its unique qualities and properties, it transmits, absorbs and reflects light. If we want to deepen and appreciate the merits of art glass, we should say that its historical accumulation, for centuries, is the reason 
for the richness of this material. A look into the past reveals technical and aesthetic possibilities that can be applied to the modern presence of glass, both in art and in everyday life and architecture. The history of glass can be traced in different periods from its discovery in Antiquity, through Hellenism, its heyday in the Roman era, to the Middle Ages, Renaissance, Baroque, Enlightenment and to the nineteenth and twentieth centuries, marked by industrialization. The finely crafted various household items that have reached us since antiquity still impresses us. We will not go so far back in the origin of the material and its earlier samples. There are enough extensive materials for its development over the centuries, although not unanimous about its origin. As a starting point, we will accept the moment when the presence of glass is already significant and inextricably linked to our lives. We will take a closer look at glass in the context of mid-nineteenth and early twentieth-century art. It was then that this industrial entry into the artistic process took place, which overturned our notions of creating art and the role of its author.

There are many theories and even legends about the origin of glass, all united around chance. The Roman author, naturalist and natural philosopher Gaius Plinius Secundus, known as Pliny the Elder, was the first to write about this highly valuable material in his work Natural History, in which all the knowledge of antiquity was gathered. He lived in the first century of the new era. According to him, a Phoenician ship carrying soda was forced by a strong storm to dock in a small bay. In those days, the Phoenicians extracted soda from seaweed and it was in the form of large lumps. It was mainly used for softening wool, washing and embalming. The sailors landed on a sandy shore with no rocks. They thought they could use lumps of soda instead of stones to make a hearth and eat. The storm passed. As they left, scattering the hearth, they noticed some shiny pieces in the ashes that did not look like metal, either stone, or clay. According to Pliny, these mysterious little pieces were glass, a melt made by heating sand from the shore and lumps of soda.

For many years, historians copied history from Pliny and believed that in this way the glass was obtained for the first time. More recently, glassmakers have experimented with recreating the conditions, under which the Phoenicians once discovered pieces of glass. The researchers did not find a trace of glass in the ashes, because the weak heat given by the flame of the hearth is not enough to combine soda with sand and form glass. Thus, another of the legends accompanying the origin of the material was debunked.

From ancient to today's industrial glass has accumulated a long and dynamic history, tracing the development, distribution and use of this intriguing material. The beginning of the nineteenth century was a time when new industrial techniques were 
taking over the world. As often happens, with the advent of innovation in everyday life, people are divided into two main groups. The former denies the benefits and continues to rely on the known, on the principle that misunderstanding leads to denial. The other group sees new opportunities and is looking for an application. Expands the field of action and experiments, changes boundaries.

With the emergence of an English movement called Arts and Crafts, preaching a trend to restore the craft process and the formation of attitudes and tastes in the audience, different from the fashion in moment, the change was born. This group of like-minded people was led by William Morris, lived 1834-1896. They prioritized the conservation of crafts, which were most threatened with extinction due to mass industrialization. The group rejected the technological process, fearing that the artist's role would be replaced by impersonal machines.

Decades later, this movement is believed to have laid the groundwork for the advent of the Art Nouveau style. But there, contrary to their beliefs, technological progress and art found a crossroads. The new style - Modern, as it was called at that time in Bulgaria - conquered all manifestations of art, design and architecture. Art Nouveau did not divide art into fine and applied, it sought to make it part of everyday life with an emphasis on attention to the detail. Floral motifs, wavy shapes are typical, often the combination of new and expensive materials. With a strong focus on aesthetic impact and inspired mainly by nature in all its beauty and diversity. In the development of art glass, this period marked a real upsurge in the creation of jewelry patterns. Here we will mention three innovators who contributed to the connection between mechanized production and the high artistic merits of the works of that time and more precisely of these samples created from glass. Can their achievements be called works of fine art today?

Emile Galle is an artist born in 1846. in Nancy, France. He is considered as a pioneer of technical innovations in glass. Galle is the son of a successful manufacturer of faience and furniture. The young Galle studied philosophy, botany and painting, and later glass in Meisenthal, France. After Franco-Prussian war of 1870-71, he began work in the family factory in Nancy. Initially, he experimented with colorless and slightly colored glass, decorated with enamels and engraved. Subsequently, it works with color-saturated, almost no transparent and thick, heavy glass. They are multilayered with different thickness, from which by engraving and etching created the floral motifs characteristic of his work and the whole Art Nouveau style (Fig. 1). They brought him great success at the World's Fair in 1878 in Paris. After that moment Galle gained international fame. He established his own factory for mass production of glass objects according to his design. There he 
attracted various artists, where together they followed the whole process and with their technical skills were responsible for the authenticity of Galle's original project. Despite the mechanized processes, his works were highly valued both in Europe and abroad. The factory was an example of how the art form - creation can be achieved in serial production. Emile Galle wrote a book entitled Writings on Art /Écrits pour l'art/ 1884-1889, which was published in 1908, four years after his death. He is an iconic figure for his time both as an artist and as a public figure.

Another significant author and representative of Art Nouveau is Rene Jules Lalique. He was born in 1860 in Ay, near Marne, France. A few years later his family moved to Paris, but he remained deeply connected to his home-place, where Lalique continued to spend his holidays. After the death of his father, Rene Lalique began apprenticeship with the famous jeweler Louis Aucoc.

At the same time, he studied classical jewelry techniques at the Graduate School of Fine Arts in Paris. He then developed his skills in London for another two years. Upon his return to Paris, he was a freelance designer, gradually gaining popularity and managing to collaborate with companies such as Cartier and Boucheron. He became famous as one of the leading designers of the Art Nouveau style in 1887. and founded his company in Paris. Creates jewelry in which he includes new materials. The materials occupy a central place in the Lalique's design. His creative pursuits are aimed at creating something new and unprecedented. Lalique combines precious and semi-precious stones, pearls, ivory, enamel and of course glass. He created his own glass studio, from which came the first jewelry made of metal and glass. Gradually, his attraction to this material went beyond jewelry, especially when he met perfume expert Francois Coty. He is impressed by the design of some objects that Lalique has already created from glass. Coty offers him to design glass bottles for the perfume industry (Fig. 2). This opens a new world for Lalique. In 1921 he already had his own glass factory in Alsace, France. The French designer, jeweler and glass maker holds the artistic approach and attention in industrial production, as does Galle. A variety of utilitarian items were produced. From the Art Nouveau style that marked the beginning of his career, he moved to the Art Deco style and its more geometric shapes.

After the death of Rene Lalique in 1945, his son Mark Lalique took over the company continues the tradition of innovative approach by introducing the use of crystal glass in mass production. He expands the range offered and leads the heritage company extremely successfully. To this day, this successful collaboration between design and craft, between glass and metal, continues to exist, taken over by a Swiss group. The name Lalique continues to be a symbol of quality and design works. 
At that time in the United States, another bright representative of the Art Nouveau style left his mark on art glass and intertwined exquisitely and applied. Lous Comfort Tiffany was born in 1848 in New York, USA to the family of the famous jeweler Charles Louis Tiffany. Among his main contributions to the development of glass, as an artistic material from the late nineteenth and early twentieth century is his patented technology for opal / totally non transparent/ glass. In addition to being opal, this glass combines a variety of colors and shades in itself, reminiscent of watercolor paintings. Today, these spectacular glasses are well known and used by glassmakers around the world. Another important innovation came from the American author was the unification of the opal pieces into a common project, not through brass, lead or zinc slats, as in the classic stained glass, but through copper tape. The copper foil tape is softer and lighter than the spruce ones and provides more freedom when working. Today, this technique is known as its creator 'Tiffany'. This technique creates lighting fixtures and other smaller works, such as two-dimensional and three-dimensional art objects (Fig. 3).

\section{2.}

Having knowledge of the beginning of this process of collaboration, can we clearly define where the line is today between the exquisite and the applied in the fine arts? After the strong penetration of technology in many aspects of our lives, the dividing line is not so clear, both for the authors and for the works and the audience. Do we liken the works in categories or do we fit everything into one common contemporary art? Over the centuries, the status of the artist has changed from a craftsman through an academic author to a free and independent artist. Today's postmodern society has long since destroyed the line between fine, applied, craft and modern technology. Coincidence or the tool take responsibility for creating a work? Everything is allowed and everyone is an artist, and if he has his own audience, it is considered to be successful. Often the work does not fall into only one genre, the author does not profile himself to work in one field. He is everywhere understanding, critical and active in an attempt to be always up to date. Radical freedom in art is in vogue. But where does this freedom in the means of expression really lead us and how do we form our attitude towards contemporary art? What is the relation of the function to works of our modern art? We are used to arranging our surroundings, facilitating our own assimilation of information, by labeling and carefully dividing everything into categories. Determining the classification of the work is the context in which it lives. When utilitarian objects from our everyday life are deprived of their function and presented as sculptural objects, for example, does 
our attitude towards them change? Broken glass thrown on the street may be completely unnecessary, but exposed in an artistic space, dressed in a concept and bearing a title, it becomes modern art. The practical thing is transformed into an artistic one by changing its function. More and more often familiar things from our surrounding are offered to us as a finished work, which is realized in a durable material. Of course, here the prototype that introduced the term 'ready-made', in 1912, was Marcel Duchamp. Although modest in volume, he had a significant influence on the formation of such trends in art in the second half of the 20th century, such as pop art, minimalism, conceptual art and others. In his constant search for a new, original presentation and attracting a wider audience, the contemporary artist boldly embarks on experimenting with a variety of techniques and materials, for which, however, we can now make a similar reference to the recent past. Mixing and superimposing styles, techniques and borrowings from our everyday life, in search of identity, actually totally blurs the framework, but it also seems that it increasingly depersonalizes contemporary art. As far as painting is concerned, we have long considered individual authors to be fundamental in a given field. For works in this field it is easier to formulate to which style to refer them and from which artist, the author is inspired. And what is the development of applied art and in particular utilitarian objects and personal accessories from our everyday life? Somewhere there, between the fine and the applied, a separate and strongly developing category has formed - "art object". In this category it is comfortable and wide. We can fit in there without definitely identifying with an existing genre. Without setting clear boundaries and meeting expectations. In the role as an author, using mainly the material glass as a means of expression, a shift between the exquisite and the applied is often felt (Fig. 4, 5, 6, 7).

In fact, these are also lighting fixtures, this is their function, it is real, but it is desirable rather than basic. No one relies on illuminating a specific environment with them. Design boldly intervenes here. It is a characteristic feature of the art object. Without a serious dose of design approach, the object would be just a practical thing. The design makes the cohesion between the fine and the applied art. It gives or takes priority of the function. This twist has more than once provoked reflections on the classification of works of contemporary art, which is on the path to commercialization. Involved in everyday life, but also striving to differentiate himself from it. In the category 'Object' find those creative searches, subordinated to the notion of unified presentation and overall construction. The feature is often present, but not required. The object is perceived as a work of art in itself. This genre very 
friendly and helpful invites all authors, hesitant in the many styles, definitions and details.

Let's look at another example of those made of glass. The enlarged, glass pills of the American author and designer Beverly Fishman (Fig. 8), clearly illustrate the relationship between design, craft, exquisite work and a direct borrowing from our trivial round, presented in an artistic form. There is no function here, but the objects are perceived quickly and clearly. Out of the practicality of purely utilitarian objects and the framework of church-stained glass, glass is now widely used in contemporary art. By adding the word 'artistic', we are actually supplement a unit of measure for uniqueness, identity, something created once. With its technological development, its possibilities become almost limitless. It is considered a modern and multifunctional material that fits equally well in different architectural environments and in many manifestations of creative demand. Perhaps, precisely because of its versatile influence, glass works often oscillate between fine and applied art. So, it turned out that often began to occur works, under which the word 'object' is conveniently written.

They have gathered familiar elements of our everyday life in a new whole performance. Clear enough and recognizable, as 'Objects', which in itself does not carry a clear message from the author about their purpose.

Where is the subtle transition from one genre to another? How can we summarize what is created in one word, including the diverse manifestation of this type of works - objects? In the case of the specific glass aforementioned, they would be equally distinctly presented in an exhibition hall and in an interior. The spaces themselves are also changing their approach, they are flexible. Various events, including exhibitions, take place in the same place. We live in a time of multidisciplinary artists using mixed techniques, presenting their art in alternative spaces. It is important that new cultural experiences take place. In our global world, where the mass culture has settled comfortably, the unification of the offered goods and products is more and more often observed.

The author, in turn, in his quest to be relevant, but still to remain an artist, tries to offer the audience something new and unseen. But let us consider the connection between the abstract art object and the real context in which it appears or it continues to exist and be 'used'. Is the material that makes up the work and the environment in which it lives help to classify it? How would we choose to use an object that can be exhibited in an artistic space, but could also be functional (Fig. 9).

Does this freedom of expression make us freer artists or do we feel dissatisfied with the fact that everything is already exhausted? Seeking our personal identification, 
we do not bring our ideas as authors to an end. We use real-life borrowings that are easily digestible and reach the audience quickly. Contemporary art is part of mass culture or at least very often uses it. We jump into new experiments, where the combination of design, craft, technology and modern attitude for artistically sustained works are somehow a natural process that we are obliged to follow. The packaging is often leading. Content is of secondary importance. And since anyone can easily become an artist, why not turn everything into art? In the realization that everything has already been done somewhere by someone, are we not looking for salvation by returning to the craft?! Thus, demonstrating how well we have mastered and subdued the material, we actually use the qualities of glass for the closest imitation to everyday things. However, so, created and presented to the public, we have the right to call them works of modern art glass (Fig. 10).

\section{Conclusion}

Figuratively speaking, on the one hand, today anyone can be an artist without requiring education or practice. There is no hierarchy of achievements. This is due to technological progress and the wide supply of all kinds of artistic materials. It is technology that provides us with easy access to create works that require much more effort and knowledge in the past. At a hobby level, everyone can experiment and present the result as something unique. And it really is, because it is not repeatable, but often it is on the principle of chance. On the other hand, artists who have gone through all stages of training and practice often realize that in the times we live in, it would be difficult to offer the world something unseen.

Thus, we subconsciously look for an alternative, such as recreating real things with artistic mastery. Of course, this trend extends far beyond glass objects. On the other hand, this globalization makes us a true citizen of the world. Believe that Contemporary art follows general trends everywhere. Objects are a new form of presentation of works of art, falling simultaneously into different categories or an attempt to add an artistic moment to real things and objects. And yet everything set out so far is relative. Each painting, sculpture, utilitarian form or object carries individual aesthetic qualities and is more or less similar, arising or denying something already seen. We have long been at a stage where it will be unlikely to point out a work of art that does not remind us of anything else or at least manages to surprise us. Personal interpretation on everything created and its upgrading through what we now have has already become essential - knowledge, technology, examples from the past. And last but not least, today, it seems to me, the concept and packaging of 
things often displace the content. For which genre the work is classified is insignificant, compared to how it is presented.

\section{References:}

Battie, D.; Simon, C. (1991). Consise Encyclopedia of Glass. London: Octopus Limited. Beveridge, P., Domenech, I., Pascual, E. (2003). Warm glass. New York: Sterling Publishing Co.

Bray, C. (2001). Dictionary of Glass. London: A\&C Black Publishers.

Cunningham, J.M. Britannica (2011, February 15). Retrieved October 5, 2020 from https://www.britannica.com/biography/Rene-Lalique

Drahotova, O. (1981). The Art of Glass in Europe. Madrid: Libsa.

Halem, H. (1993). Glass notes. Kent: Franklin Mills Press.

Morse Museum of American Art. Lous Comfort Tiffany (2011, October 5). Retrieved October 1, 2020 from http://www.morsemuseum.org/louiscomfort-tiffany

Stefanov, Y. (2004). From aesthetics to sociology of art. Sofia: Askony. (in Bulgarian)

Valchev, K. (2004). Glass as Art. Sofia: NBU. (in Bulgarian) 


\section{Appendix}

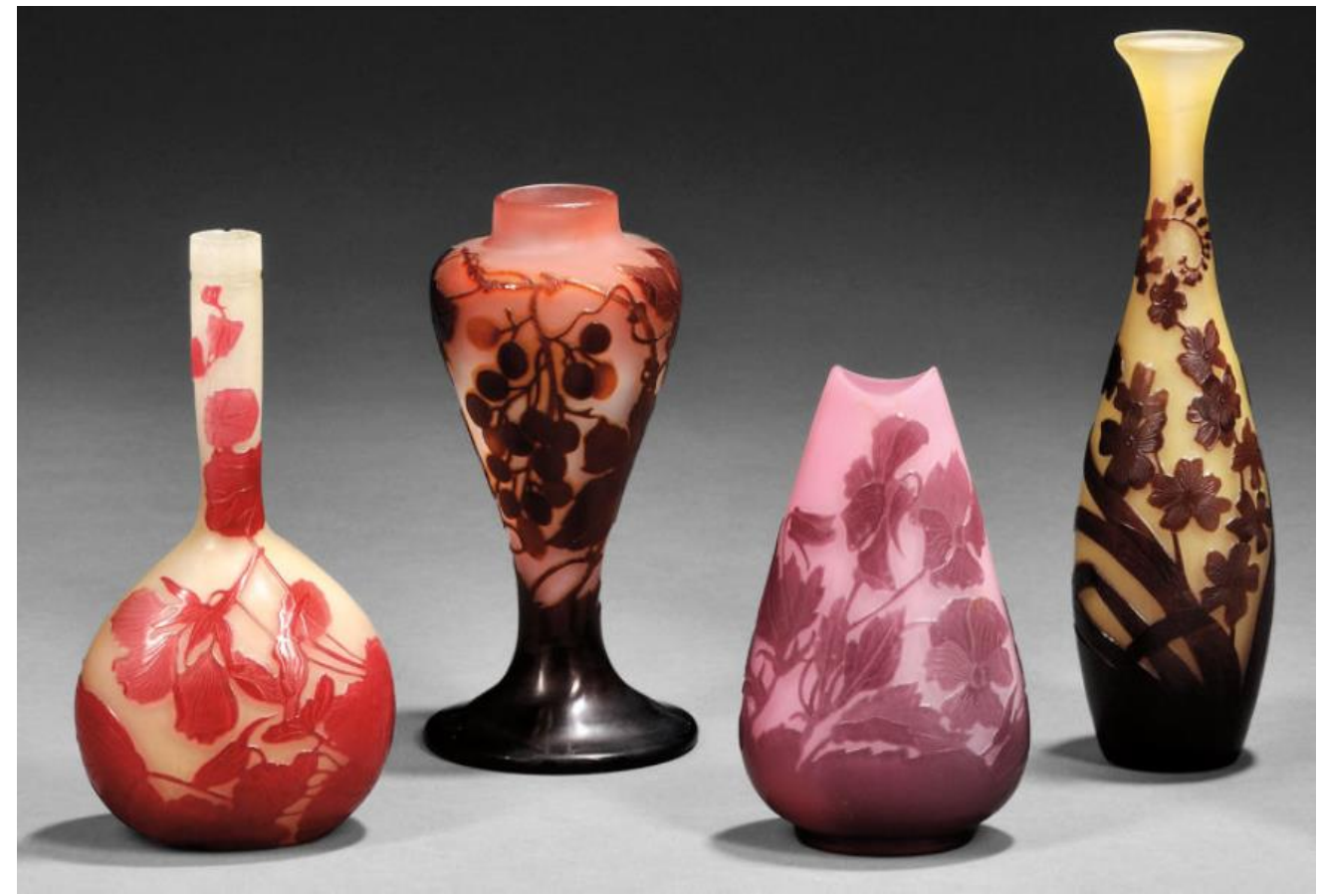

Figure 1. Emile Galle vases, in Art Nouveau style with floral motifs. Photo source [app. 1]

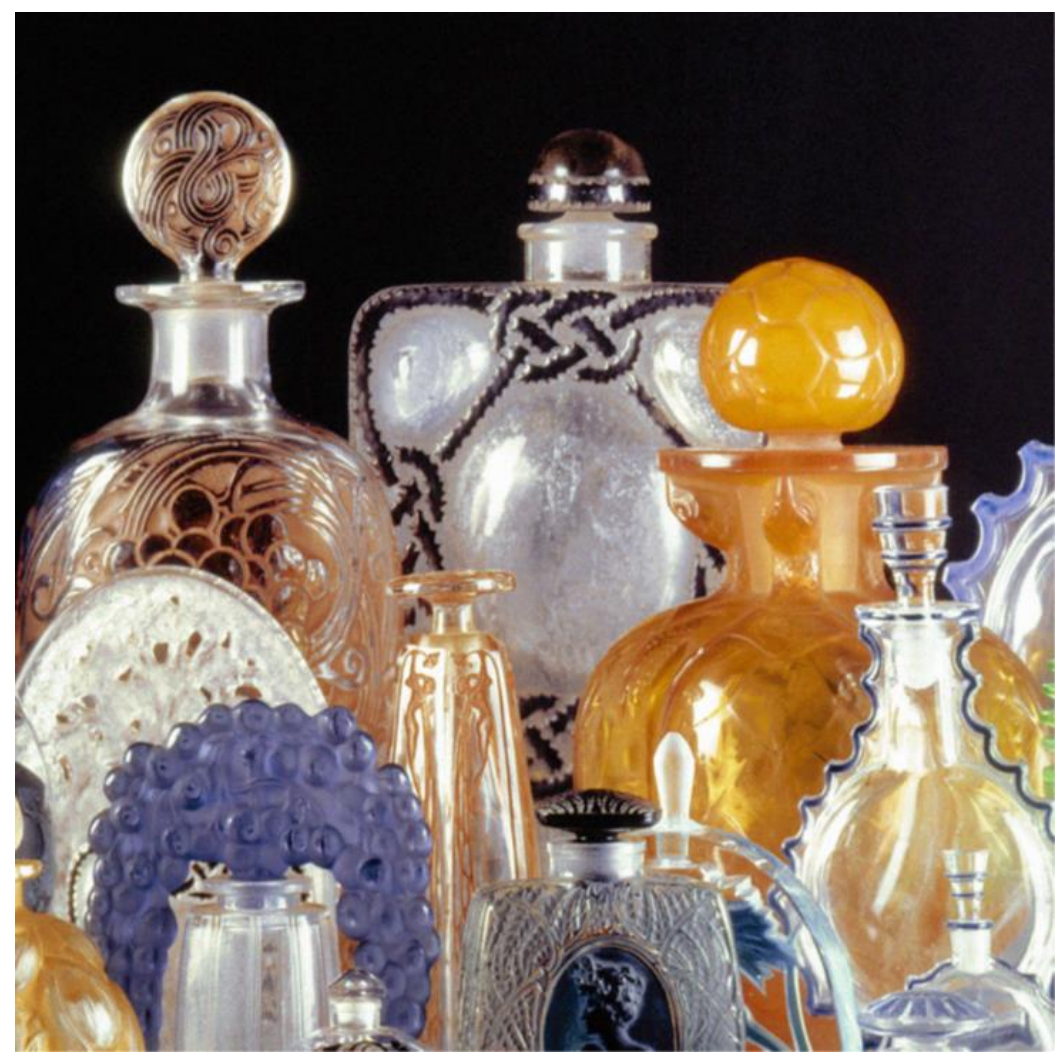

Figure 2. Rene Lalique, perfume bottles [app. 2] 


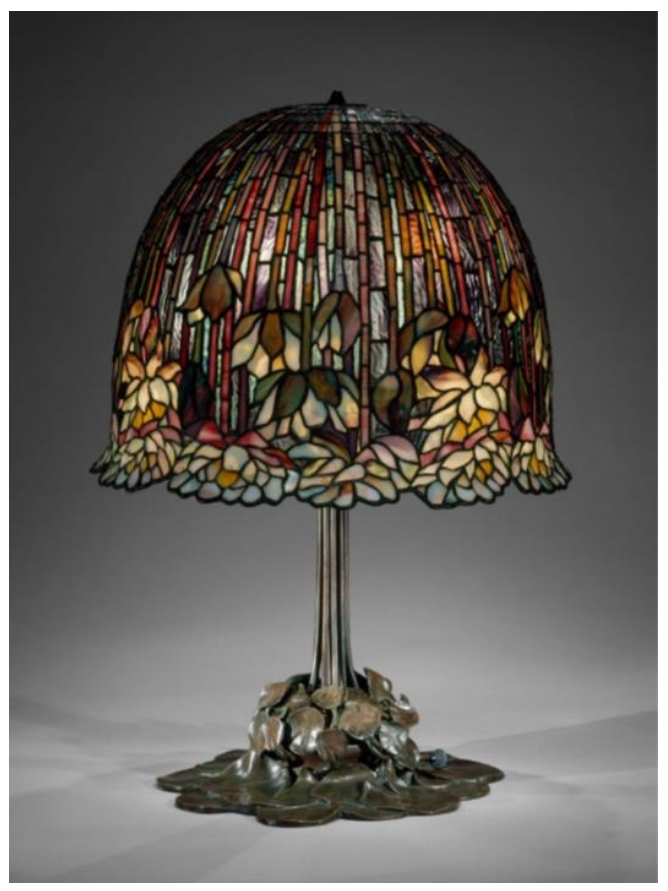

Figure 3. Louis Comfort Tiffany, lamp [app. 3]

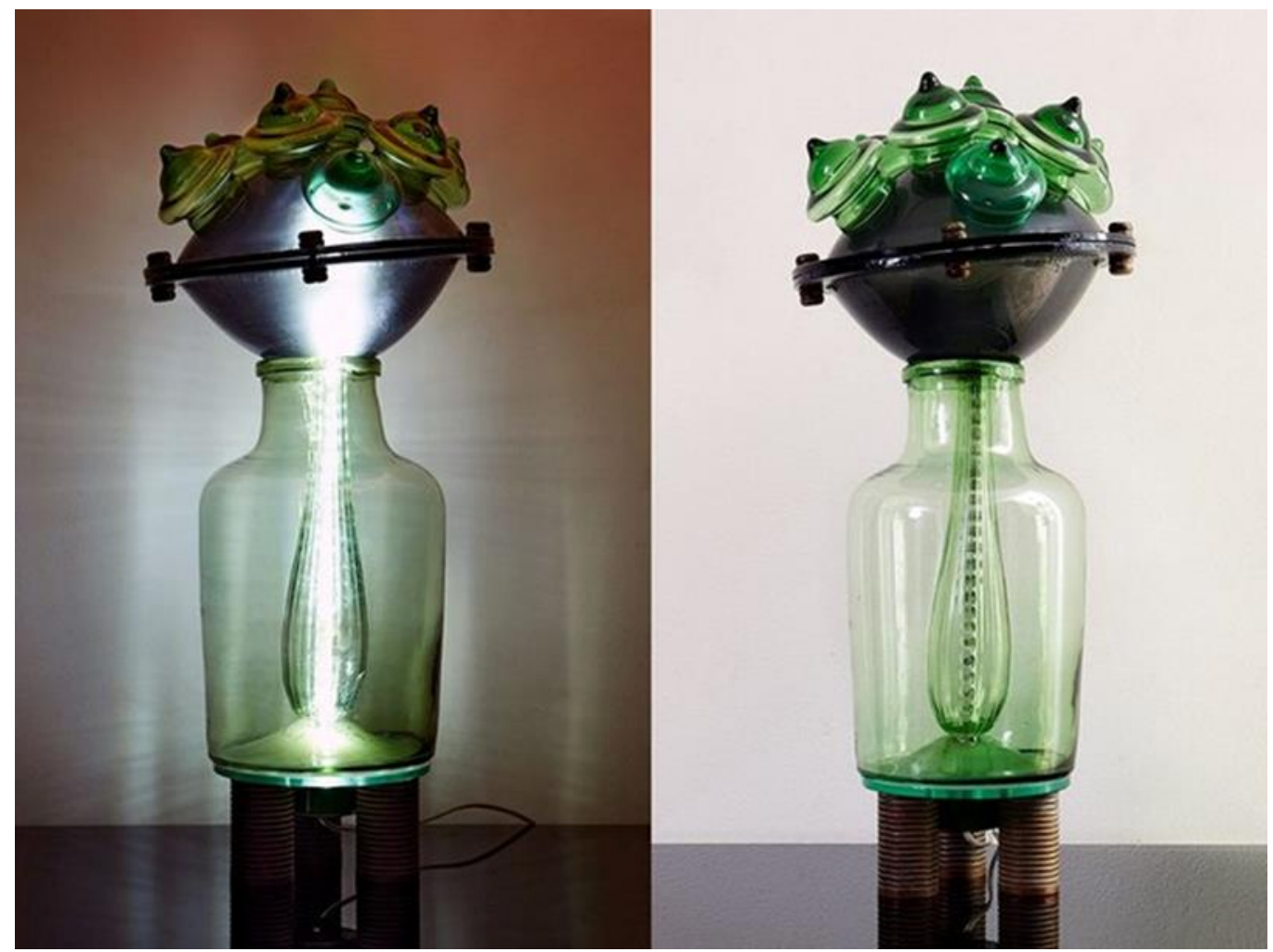

Figures 4, 5. Artist: Monika Naydenova, luminous object, source: personal archive 


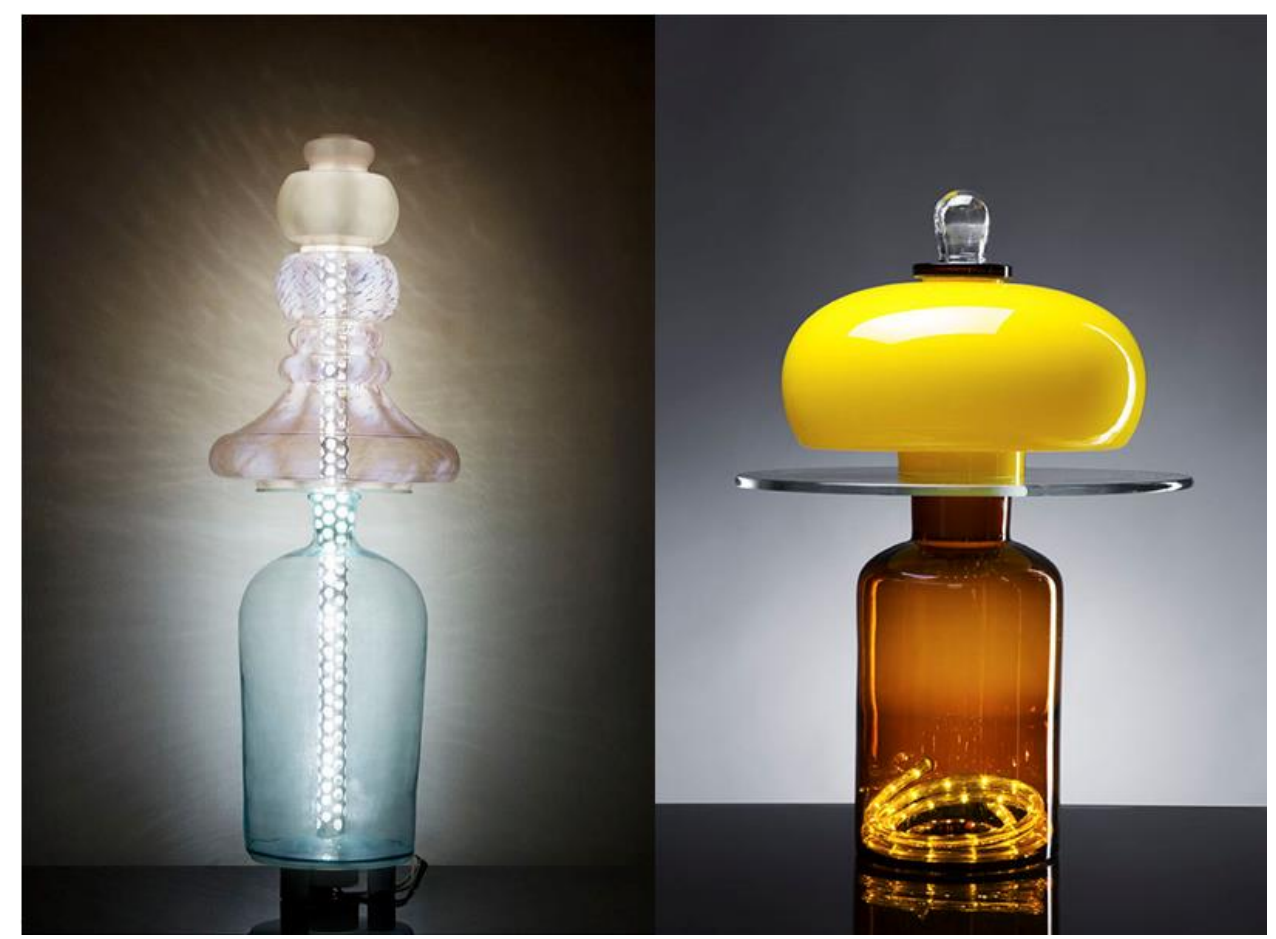

Figures 6, 7. Artist: Monika Naydenova, luminous objects, source: personal archive

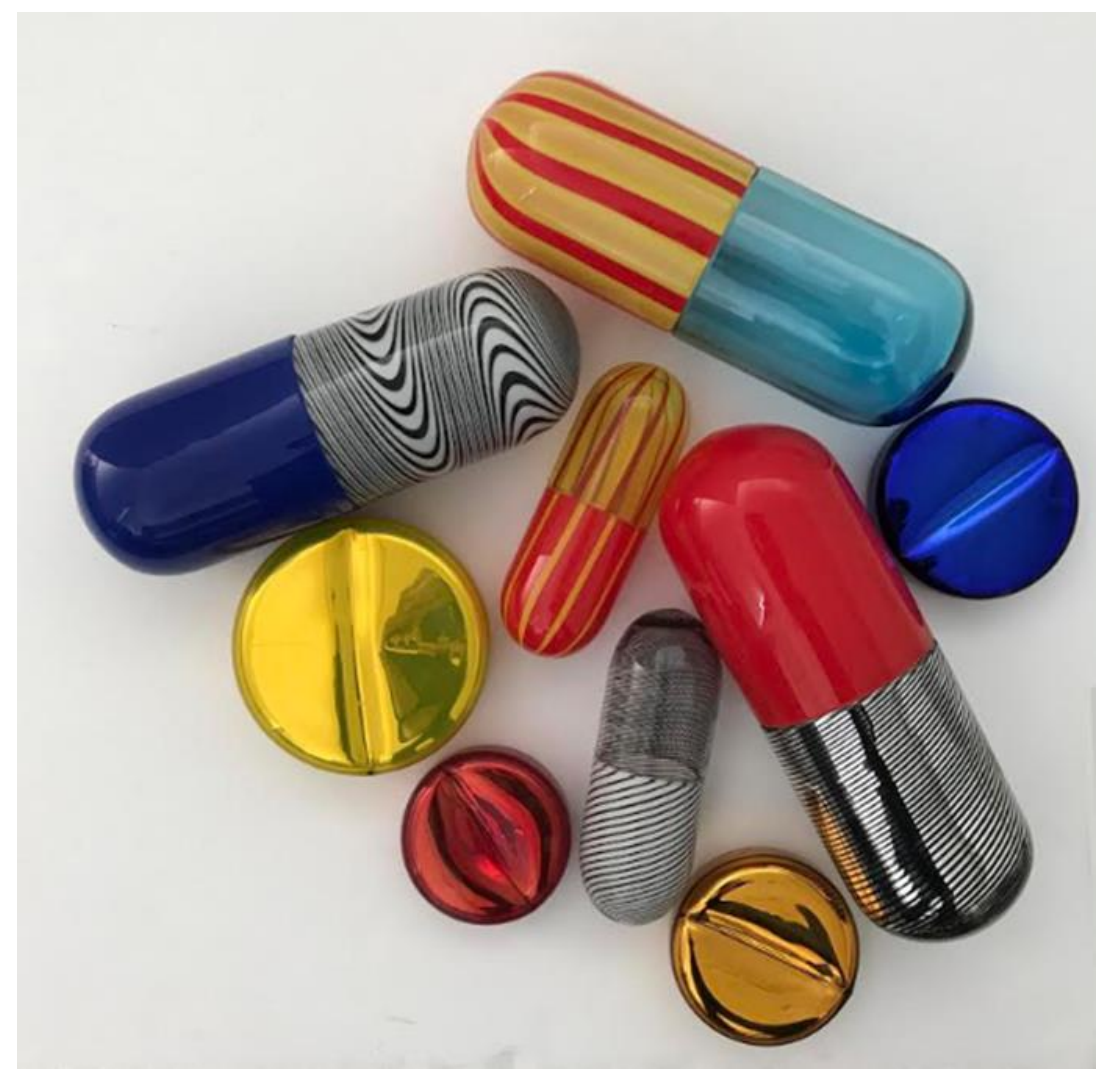

Figure 8. Artist: Beverly Fishman, Glass pills [app. 4] 


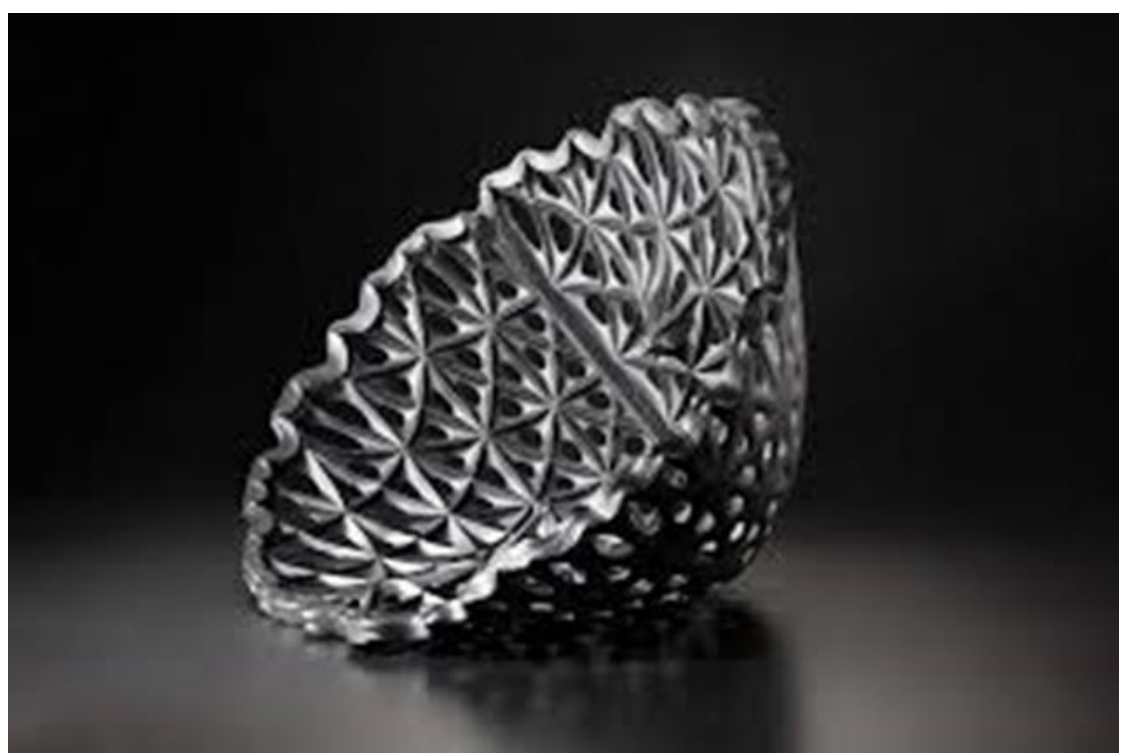

Figure 9. Artist: Milan Krajiček [app. 5]

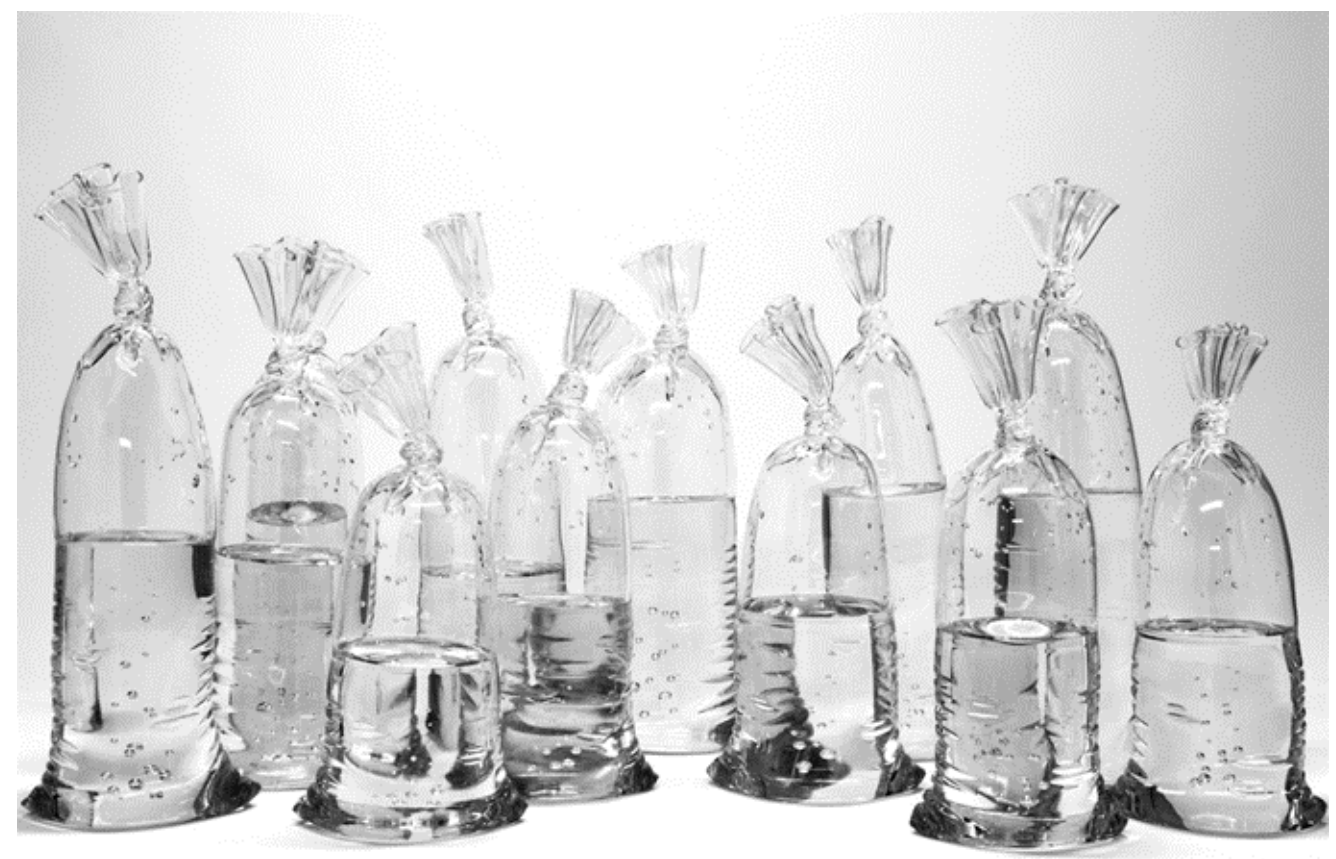

Figure 10. Dylan Martinez, glass bags 


\section{Appendix References:}

Retrieved September 15, 2020 from

https://www.skinnerinc.com/news/blog/emille-galle-artnouveau-glass/

Retrieved September 15, 2020 from http://www.lalique.com/en/world-oflalique/lalique-timeline

Retrieved September 15, 2020 from http://www.metmuseum.org/toah/hd/tiff/hd_tiff.htm

Retrieved September 15, 2020 from https://www.gavlakgallery.com/artists/beverly-fishman?view=slider\#4

Retrieved September 15, 2020 from https://www.akademie-svetla.cz/odbornecv/908-mga-milan-krajicek

Retrieved September 15, 2020 from https://aworkstation.com/glass-sculptures-bydylan-martinez-perfectly-imitate-water-filled-plastic-bags/ 